\title{
MEDICINE AND THE STATE
}

THE TENDENCY for politicians to meddle in the practice of medicine appears to be as old as recorded history. The archaeologists have provided us with details of the penalties imposed by the State on practitioners of ancient Babylon who failed to cure their patients. Today there is hardly a politician extant who does not publicly subscribe in some form to the creed that government can manage the provision of medical care better than the doctors.

With every political party in Canada looking to medical care as the next thing which may be given "free" in return for loyalty at the polls, it is time for the physician to make an effort to develop some clarity in his thinking in this matterto know what he thinks, and why.

It is a great misfortune that some proponents of State-sponsored medical schemes seem to feel that they will gain their point by attacking the profession of medicine. The doctors are represented as "money grubbers," denying medical care to those unable to pay for it, growing fat on the misfortunes of others. Certainly all this sounds strange in a land which enjoys one of the highest standards of medical care in the world - where no one need lack for medical care who needs it, or who thinks he needs it, regardless of his ability to pay. Surely the least likely way to gain the sympathy and co-operation of the profession is to sneer at its ideals and besmirch its reputation. The doctor cannot be blamed under these circumstances if he begins his consideration of this problem with the firm conviction that the proponents of State medical schemes are not truly interested in the improvement of medical care, but only in selling more newspapers or buying more votes.

Undoubtedly there are many doctrinaire socialists who believe that everything can be done better by the State. Without the necessity of agreeing with their philosophies, one can at least respect them for their sincerity. These people and many less sincere are quite unable to understand the physician's opposition to State control of medical practice, because the professional attitudes of medicine are completely foreign to them. Physicians tend to forget that most of mankind: works only to make a living, and that basically most men consider work as something distasteful which they would gladly avoid. This means that most of our society works only for money, and they fail completely to understand that the professional man can have any other motivation. By this reasoning, any opposition by the profession to the encroachment of third parties in the control of medical practice is interpreted as an attempt to preserve the monetary rewards of practice; and from this it follows in some minds that if the profession is so anxious to preserve the statús quo, the incomes of doctors must be too high. Q.E.D.! 
Any intelligent man who wishes to consider the facts dispassionately will be aware that the financial returns of the practice of medicine are not likely to change much because the physician's fee comes from the public rather than the private purse. What then are the doctors fighting about?

An elementary and serious error which is evident particularly in the daily press is the failure to distinguish between a health insurance plan, to which the state may contribute, and a state-controlled medical care plan, which must ultimately interfere with the physician's treatment of his patient. The primary interest of the medical profession is that the practitioner shall retain the freedom to provide for his patient the best care and the best treatment available. The best care and the best treatment mean that the best of equipment, drugs, and technical assistance must be available, and that there must be no deterrent to their use. These things cost money. Money spent to maintain an unnecessary administrative bureaucracy is no longer available to provide these essentials of good medical care-and governmental control and a budget for medical care means that administrative costs will have first call on the budget, and that the medical care of the community will be regulated by the amount of money which is left after this requirement is met. Experience elsewhere has shown that pressures are applied to the physician in order to balance the budget, which either make it impossible for him to give his patients the attention and care which they require and deserve, or influence his treatment of them.

No satisfactory solution to the divergence of views on this subject can be possible until the politicians and the press cease their ridiculous attacks on the attitude of physicians to the treatment of their patients, and make some attempt to understand the professional attitude. On the other hand, the public is not likely to come to understand the issue until the doctors stop talking ambiguously about the prospect of deterioration of medical service under government control, and begin to know and to say exrctly what they mean. This is no matter for woolly thoughts and woolly words 


\section{LA MEDECINE ET L'ETAT}

LA TENDANCE qu'ont les politiciens de s'immiscer dans la pratique de la médecine nous semble aussi vieille que l'histoire elle-même. Les archéologues nous fournis: sent des détails sur les punitions imposées par l'etat aux practiciens de l'ancienne Babylone qui ne réussissaient pas à guérir leurs malades. Aujourd'hui, rares sont les politiciens qui, publiquement, ne souscrivent pas sous quelque forme a l'assurance que le gouvernement peut organiser le paiement du coat des soins médicaux mieux que les médecins.

Etant donné que tous les partis politiques au Canada se retournent actuellement vers les soins médicaux comme étant la prochaine chose qu'ils aimeraient a donner gratuitement en reconnássance d'un vote bien placé au bureau de votation, il est temps que le médecin fasse un effort pour clarifier ses idées sur ce sujet-qu'il sache' ce qu'il pense et pourquoi il le pense.

- Il est bien malheureux que les préconisateurs de plans de soins médicaux payés par l'état soient sous l'impression que c'est en attaquant la profession médicale qu'ils vont gagner leur point. Ils décrivent les médecins comme des assoiffés d'argent, refusant leurs soins à ceux qui ne peuvent pas payer et augmentant leur pécule au détriment des malheureux. Sans aucun doute, ces discours nous semblent un peu étranges dans un pays qui possède les plus hauts standards de soins médicaux dans l'univers, pays où quiconque a besoin de soins médicaux ou croit en avoir besoin peut en avoir, qu'il puisse ou non payer. Un des moyens les plus sûrs de s'aliéner la sympathie et la coopération de la profession est de se moquer de son idéal et de salir sa réputation. Peut-on blâmer le médecin, en de semblables circonstances, s'il aborde l'étude de ce problème avec la ferme conviction que les préconisateurs de plans d'assurance-santé ne sont nullement intéressés à améliorer les soins médicaux, mais plutôt à vendre plus de journaux et à acheter plus de votes.

Sans doute il existe plusieurs doctrines socialistes qui sont sous l'impression que, par l'état, tout peut être mieux fait. Sans accepter leur philosophie, nous pouvons toutefois les respecter à cause de leur sincérité. Ces gens et un grand nombre d'autres moins sincères sont tout à fait incapables de comprendre pourquoi le médecin s'oppose au contrôle de la pratique médicale par l'état, parce qu'ils ignorent tout des attitudes professionnelles de la médecine. Les médecins semblent oublier que la plupart des hommes ne travaillent que pour gagner leur vie et que, foncièrement, la majorité considère le travail comme une chose désagréable et sans attrait qu'elle serait bien contente de laisser tomber. Cela vient à dire la plus grande partie de notre société ne travaille que pour l'argent et on ne peut pas se mettre dans l'idée que le professionnel puisse avoir d'autres motifs d'action. En raisonnant ainsi, toute opposition de la part de la profession à l'empiètement d'un tiers dans le contrôle de la pratique médicale est interprétée 
comme un désir de protéger les récompenses monétaires de la pratique médicale; puis, de cela, d'après certains, le raisonnement suivant découle: si la profession désire tellement que lès choses ne changent pas, c'est que les revenus des médecins doivent être trop élevés!

Toute personne intelligente qui veut étudier les faits objectivement réalisera que les revenus économiques de la pratique médicale ne seront pas susceptibles de changer beaucoup parce que les honoraires médicaux seront payés à même les deniers publics plutôt qu'à même la bourse du particulier. Mais alors, pourquoi les médecins demeurent-ils opposés?

Une erreur élémentaire mais sérieuse que l'on rencontre particulièrement dans les journaux quotidiens, c'est le manque de distinction que l'on semble faire entre un plan d'assurance-santé auquel l'état peut contribuer et un plan pour soins médicaux contrôlé par l'état qui, en définitive, va intervenir dans le traitement du malade. Le principal intérêt de la profession médicale consiste en ce que le praticien demeure libre de prodiguer à son malade les meilleurs soins et les meilleurs traitements qu'il connaisse. Quand on dit: meilleurs soins et meilleurs traitements, cela signifie le meilleur outillage, les meilleurs médicaments, la meilleure assistance technique que l'on puisse souhaiter et surtout qu'il n'existe pas d'empêchement à leur emploi. Tout cela coate de l'argent. Puis l'argent dépensé pour entretenir une bureaucratie administrative inutile ne peut plus servir à l'achat de ce choses essentielles aux bons soins médicaux; alors le contrôle gouvernemental et un budget pour les soins médicaux laissent entendre que les frais d'administration vont amputer le budget et que les soins médicaux de la population vont être soumis et proportionnels aux sommes d'argent qui resteront après les dépenses payées. Les expériences vécues à l'étranger nous apprennent qu'il s'exerce des pressions sur les médecins pour balancer le budget ce que les place dans la situation ou bien de ne pas donner à leurs malades l'attention et les soins qu'ils requièrent et qu'ils méritent, ou bien d'influencer le cout des traitements à leur donner.

Nous ne voyons pas d'issue satisfaisante à cette divergence de vue sur ce sujet, à moins que les politiciens et la presse ne cessent leurs attaques ridicules sur l'attitude des médecins à l'égard des traitements à leurs malades et qu'ils ne fassent des efforts pour comprendre l'attitude professionnelle. D'autre part, le public ne parviendra pas à comprendre l'enjeu à moins que les médecins ne cessent de parler de façon ambigue sur la possibilité de détérioration du service médical sous le contrôle du gouvernement et qu'ils commencent à savoir et à dire exactement ce qu'ils pensent. Ce n'est pas le sujet ni le moment où il faudrait avoir des idées confuses exprimées en termes couverts. 